\title{
Matematik Öğretmenlerinin Akran Denetimine İlişkin Görüşleri
}

\section{Opinions of Mathematics Teachers on Peer Supervision}

\author{
Yeliz ÖZKAN-HIDIROĞLU* (D) Çağlar Naci HIDIROĞLU** \\ Abdurrahman TANRIÖĞEN***
}

Received: 21 October 2018

Research Article

Accepted: 20 November 2018

\begin{abstract}
The aim of this study is to investigate the opinions of math teachers on peer supervision. The research is a case study, which is a type of qualitative research methods. The participants of the study consist of 9 math teachers, chosen with maximum variation sampling method, who work in seven different geographical regions of Turkey. Qualitative data were obtained from the interviews conducted with the semi-structured interview form. In the analysis of the data, content analysis was used. As a result of the data analysis in the research two main categories (pre-conditional features and process-oriented features) and nine subcategories based on these emerged. The main category of pre-conditional features is categorized with the subcategories of supervisor's being teacher, physical equipment and bureaucratic conditions while the other main category process-oriented features is categorized with the subcategories of objective supervision, supporting development, analyzing the problems, effective communication, collaborative supervision and environment of trust. It is thought that peer supervision can be applied as an alternative method in supervision. In current practice, supervisors/ principals may make teachers feel that they believe in the teachers and encourage them for professional development. The effects of these applications can be examined by applying a peer supervision model designed with math teachers.
\end{abstract}

Keywords: peer supervision, mathematics teacher, supervision.

ÖZ: Araştırmanın amacı, matematik öğretmenlerinin akran denetimine ilişkin görüşlerinin incelenmesidir. Araştırma, nitel araştırma türlerinden durum çalışmasıdır. Araştırmanın katılımcıları, maksimum çeşitlilik örnekleme yöntemiyle seçilen, Türkiye'nin yedi farklı coğrafi bölgesinde görev yapan dokuz matematik öğretmenidir. Veriler yarı yapılandırılmış görüşme formu ile elde edilmiştir. Verilerin analizinde içerik analizinden yararlanılmıştır. Verilerin analizi sonucunda iki temel kategori (ön koşul özellikler ve süreç özellikleri) altında dokuz alt kategori ortaya çıkartılmıştır. Ön koşul özellikler; denetmenin öğretmen olması, fiziksel donanım, bürokratik durumlar alt kategorilerinden oluşurken süreç özellikleri ise; nesnel denetim, gelişim destekleme, çözümleyici olma, etkili iletişim, işbirlikli denetim ve güven ortamı alt kategorilerinden oluşmaktadır. Denetimde, alternatif bir yöntem olarak akran denetiminin uygulanabileceği düşünülmektedir. Şu anki mevcut uygulamalarda denetmenler/müdürler; öğretmenlere güvendiklerini hissettirebilir, mesleki gelişimleri adına onları cesaretlendirebilirler. Matematik öğretmenleri ile tasarlanan bir akran denetimi modeli çerçevesinde uygulama yapılarak, bu uygulamaların etkileri incelenebilir.

Anahtar kelimeler: akran denetimi, matematik öğretmeni, denetim.

\footnotetext{
Corresponding Author: Mathematics Teacher, Ministry of National Education, Denizli, Turkey, yelizozkan09@gmail.com, https://orcid.org/0000-0002-5176-1235

Asst. Prof. Dr., Pamukkale University, Denizli, Turkey, chidiroglu@ @au.edu.tr, https://orcid.org/0000-0002-37744957

*** Prof. Dr., Pamukkale University, Denizli, Turkey, atogen@pau.edu.tr, https://orcid.org/0000-0002-5491-3273

Citation Information

Özkan-Hıdıroğlu, Y., Hıdıroğlu, Ç. N., \& Tanrı̈ğen, A. (2019). Matematik öğretmenlerinin akran denetimine ilişkin görüşleri. Kuramsal Eğitimbilim Dergisi [Journal of Theoretical Educational Science], 12(2), 757-782.
} 


\section{Giriş}

Günümüzde okul denilince akla gelen en önemli öğelerden biri öğretmenlerdir. Öğretmenlik zorlu bir görevi gerektiren, en az deneyime sahipken bile güçlü sorumluluklarla karşı karşıya kalınan bir meslektir. Öğretmenler; yetersiz kaynaklar, mesleki görevlerin zor olması, açık olmayan beklentiler, bat ya da yüz mantığı ve gerçeklik şoku gibi birçok çevresel zorlukla karşılaşmaktadırlar (Apaydın, 2014). Bu zorluklar arasında kendilerinden beklenen performansları da göstermek durumundadırlar. $\mathrm{Bu}$ performanslar onlara tanınan zaman dilimlerinde mesleki etkinliklerini ve ortaya koydukları ürünleri içermektedir. Denetim ve değerlendirmenin en önemli konularından biri öğretmen performanslarının değerlendirilmesidir (Aydın, 2016). En genel anlamda performans değerlendirme, bireylerin yapacakları işe ve bu iş için sahip olduğu potansiyel özelliklere göre bireysel olarak analiz edilerek incelenmesi ve bireyin işini başarma derecesinin belirlenmesidir (Erdoğan, 1991). Yönetsel kararların doğru bir şekilde verilebilmesi için çalışanların performanslarının güçlü ve zayıf yönlerinin belirlenmesi ve bu doğrultuda yapılacak iş ve işlemler için görevlendirilmesi önemlidir (Aydın, 2016). Örgütler belirledikleri hedefleri gerçekleştirebildikleri sürece varlıklarını devam ettirebilmektedirler. Bu doğrultuda, hedeflerinin gerçekleşme ve etkililik derecesinin sürekli olarak takip edilip değerlendirilmesi örgütsel bir sorumluluk ve zorunluluktur. $\mathrm{Bu}$ adımları gerçekleştirmede denetim büyük önem taşımaktadır (Aslanargun \& Göksoy, 2013). Denetim, eğitim sistemindeki var olan uygulamaları karşılaştırmada, amaçlardan sapmaları belirlemede, bu sapmaların sebeplerini ortaya çıkarmada ve tespit edilmiş sorunlara yönelik çözüm önerileri sunma ve yönlendirmede bulunma sürecidir (Başaran, 2000; Yıldırım \& Koçak, 2008). Milli Eğitim Bakanlığı [MEB] (2000) tarafından belirlenen görevler içerisinde altı madde öğretmen denetimi ile ilgili iken; bu maddelerden ikisi de (10. ve 13. maddeler) ders denetimiyle ilgilidir.

3. Madde: Milli Eğitim Temel Kanunu'nda belirlenen temel ilke ve amaçların yanında okulun özel amaçlarını gerçekleştirebilmek için çalışma planlarını yapar, uygular ve denetler. Okuldaki eğitim-öğretim ve yönetimin bir disiplin içerisinde yürütülmesini sağlar.

9. Madde: Yıllık, ünite ve günlük planların eğitim programlarına göre hazırlanmasında ve diğer çalışmalarda öğretmenlere rehberlik eder, öğretmenlerin çalışmalarını denetler.

10.Madde: Öğretmenlerden ders yılı başında yıllık plan alır, planlan tasdik eder, uygulanıp uygulanmadığını denetler.

13.Madde: Öğretmenlerin meslekleri ile ilgili alanlarda yetişmelerini teşvik eder ve bu konuda gerekli tedbirleri alır. Ders yılının çeşitli zamanlarında öğretmenlerin derslerini ve diğer faaliyetlerini yakından izler.

18.Madde: Personelin performansını sürekli gözetip değerlendirerek, verim düşüklüğü varsa bunun sebeplerini araştırır, personelin yeteneklerini göz önünde bulundurarak istihdam eder, onlara rehberlik eder, iş başında yetişmelerini sağlar, daha üst kademeye hazırlanmalarına yardımcı olur.

49.Madde: Öğretmenlerin laboratuvar, kütüphane ve spor salonları gibi sosyal tesisleri kullanmalarını izler.

2014 yılında denetim ile ilgili yapılan düzenlemelerle birlikte okul müdürlerinin ders denetimi yapmasına ilişkin yasal bir dayanak oluşturulmuştur. İlk defa 2015-2016 eğitim-öğretim yılında okul müdürleri, öğretmenlerin ders denetimlerini yaparak performans yeterlilik notu vermişlerdir (Ergen \& Eşiyok, 2017). 2017 Eğitim 
Değerlendirme Raporu'na göre, Türkiye'de devamlılığı sağlanmış, bütüncül yaklaşımla tasarlanmış bir denetim sisteminin var olduğu söylenememektedir. TEDMEM'e (2017) göre, kurumsal karar alma süreçlerinin bir alışkanlığı olarak, denetim mekanizmasıyla ilgili sorunlar, son altı yıl içerisinde gerçekleştirilen düzenlemeler, ilgili iş ve işlemlerin tek çatı altında toplanması ve merkezileşme ile çözülmeye çalışılmaktadır. Ancak denetim sisteminin merkezileşmesi, maarif müfettişlerinin mevcut kadrolarının daraltılmasıyla ve sisteme yansıyacak olan olası sonuçlarla birlikte düşünülmelidir. Denetimde, sistemde yer alan eğitim personelinin sayıca büyüklüğü göz önünde bulundurularak planlamaya gidilmelidir (TEDMEM, 2017). Denetimde, denetlenen konumundaki öğretmenlerin bu süreçte pasif bir durumda olmaları, yani denetim sürecinin dışında tutularak mekanik bir denetlemeye maruz kalmaları en önemli sorun olarak ön plana çıkmaktadır (Aslanargun \& Göksoy, 2013). Yaklaşık 60 bin okul, 18 milyon öğrenci ve 1 milyon öğretmenin olduğu bir sistemde, denetim ve rehberlik süreçlerinde nicel eksikliklerin olduğu ve bu eksikliklerin denetim ve rehberlik faaliyetlerinin niteliğini etkilediği gözlemlenebilmektedir. $\mathrm{Bu}$ sorunların, öncelikle öğretmenlere doğru destek ve rehberlik sunabilecek bir model ya da anlayış geliştirilmesiyle ve uygulamaların düzenlenmesiyle çözülebileceği düşünülmektedir (TEDMEM, 2017). Bu doğrultuda öne çıkan alternatif denetim yaklaşımlarından birisi de akran denetimidir.

Akran denetimi, aynı branştaki öğretmenlerin birbirlerinin eğitim-öğretim uygulamalarını gözlemlemesi, bu gözlemleri meslektaşı ile paylaşması, uygulamaların etkililiğine ilişkin geri bildirimlerde bulunması ve süreçte işbirliğine dayalı bir ortamın yaratılmasıdır (Bell, 2005). Öğretmenler arasında akran dayanışmasının olduğu okullarda öğretmenler, meslektaşlarının daha iyi birer öğretmen olmalarına yardım etmekte ve öğrencilerine daha iyi bir öğrenme ortamı yaratmak için ortak sorumluluk almaktadırlar. $\mathrm{Bu}$ tür kültüre sahip okullarda; öğrencilerin nasıl daha iyi öğrenebileceklerine ilişkin paylaşımlar, işbirlikli çalışmalar ve yansıtıcı diyaloglar gözlemlenmektedir (Wahlstrom \& Louis, 2008). Meslektaş dayanışması, geleneksel okul kültüründeki özelciliğin ve yalnızlığın önüne geçmektedir. Ayrıca bu sayede öğretmenlerin enerjileri, yaratıcılıkları, etkililikleri ve birbirlerine karşı iyi niyetleri artmakta ve değişime dirençleri, sinizm ve savunuculukları azalmaktadır (Kohm \& Nance, 2009). Öğretmenlerin mesleki dayanışması mesleki gelişimin temel anahtarıdır ve bu gerçekleştiğinde okulda hem kültür hem de yapıda büyük değişiklikler başarılabilecektir (Fullan, 2000). Maarif müfettişlerinin öncelikli görevlerinden biri eğitim personeline rehberlik etmek ve destek sunmaktır. Fakat denetmen ve öğretmen arasında bir ast-üst ilişkisi yani hiyerarşi bulunmakta, bu nedenle de öğretmenlerin sorunlarını ya da sorularını denetmenlerle açıkça paylaşamadıkları düşünülmektedir. Akran denetiminde, denetimin kontrolü denetmenin elinden alınıp birlikte çalışacak iki öğretmene verilmektedir. Denetimin başarısı bu iki öğretmen arasındaki etkileşime bağlıdır. Akran denetimi, karşılıklı çıkar amacıyla birlikte çalışan iki öğretmenle gerçekleştirilmektedir. Etkili mesleki gelişim işle bütünleştirilmiştir ve süreklidir; bu anlamda akran denetimi meslektaşını gözlemlerken ayrıca kendi öğrenme-öğretme etkinliklerini planlama, sunma ve değerlendirmesini de içermektedir. Yeni öğrenme yollarını sınıfta uygulamak için izlemeyi sağlamaktadır (Gordon, 2004). Akran denetimini gerçekleştiren öğretmenlerin, meslektaşını gözlemleme, analiz etme, onunla yapıcı önerileri paylaşma becerisine sahip, akranıyla çalışmaya istekli, öğretme 
konusunda profesyonel bir tutum içerisinde ve mesleki bilgi, yeni fikir ve yaklaşımları anlama eğilimindeki kişiler olması gerekmektedir (Knoll, 1987). Ayrıca Knoll'a (1987) göre, akran denetim süreci beş basamaktan oluşmaktadır. Bunlar sırasıyla denetim amacını tanımlamak, denetim için plan yapmak, uygun bir zaman çerçevesi belirlemek, değerlendirme kriterlerini belirlemek, denetimin sonuçlarını denetmene bildireceğini belirtmektir.

Akran denetimi, birlikte çalışmak isteyen öğretmenlerle gerçekleşen bir denetim sürecini içermektedir. İyi geçinemeyen ya da yakın kişisel arkadaş olan öğretmenler meslektaşlarının derslerini gözlemlerken eşleştirilmemektedir. Akran denetim grubu düzenli olarak toplanarak öğretmenlik mesleğinin güçlükleri ve sorunları, öğretmenlerin kendilerini tanımaları (gizil güçlerini anlamaları), karşılaşılan yeni sorunlar ve çözüm yolları, okullardaki etik ikilemler ve durumlar, okullarda yaşanan zor durumlar vb. konuları tartışmaktadırlar (Knoll, 1987). Ayrıca günümüzde öğretmenlerin denetlenmesi görevi okul müdürleri tarafından gerçekleştirilmektedir. Yılmaz'a (2009) göre, okul müdürlerinin bu görevi tam olarak yerine getirmesindeki en önemli engel, okul müdürlerinin denetim ile ilgili eğitim almamış olmasıdır. Öğretmen denetiminin etkili olarak yapılmaması, onların dönüt alma mekanizmalarından en önemlilerinden birini ortadan kaldırırken; verdikleri eğitimin kalitesinin, sınıf yönetimlerinin, pedagojik, alan ve teknolojik bilgi ve becerilerinin gelişimlerinin durmasına veya daha kötüye gitmesine neden olabilir.

$\mathrm{Bu}$ çalışmada branş öğretmeniyle aynı ortamda bulunan, aynı çalışma koşullarına sahip ve ast-üst hiyerarşisi olmayan akran denetimine ilişkin matematik öğretmenlerinin görüşlerinin belirlenmesi hedeflenmiştir. Türkiye'de öğretmenlerin meslektaş gözlemine ilişkin sadece iki çalışmayla (Bozak, 2014; Bozak, Yıldırım, \& Demirtaş, 2011) karşılaşılmıştır. Gündüz ve Balyer'in (2011) çalışmasında ise meslektaş yardımı alternatif denetim yöntemleri arasında gösterilmektedir. Türkiye'deki literatürde sınırlı sayıda çalışmanın yapılması ve akran denetiminin Türkiye'de uygulanabilirliği göz önünde bulundurulduğunda çalışmanın alanyazına katkı sağlayacağı düşünülmektedir.

Ders programlarında yer alan her bir dersin ayrı ayrı rolleri bulunmaktadır. Fakat bu dersler arasında matematik dersinin ve matematik öğretmenlerinin önemi büyüktür. Nitelikli matematik öğretimi, nitelikli öğretmenler sayesinde gerçekleşmektedir. Matematik öğretmenlerinin öğrencilere öğrenmeyi öğrenme becerisi kazandırabilmesi, yaratıc1, entelektüel, araştırmacı, yenilikçi ve işbirliğine yatkın öğrenciler yetiştirebilmesi Türkiye'de matematik eğitiminde belirlenen hedeflere ulaşılmasını sağlayacaktır (Yıldızlı, 2011). Araştırmada matematik öğretmenlerinin seçilme nedenlerinden biri de PISA, TIMSS gibi uluslararası sinavlarda matematik dersinin ve matematiksel düşünme becerilerinin belirleyici olmasıdır. $\mathrm{Bu}$ dersin uzmanları ve eğitimi verenler olarak matematik öğretmenlerinin denetimleri önemli hale gelmektedir. Matematik eğitimindeki kaliteyi arttırmada da, matematik öğretmenlerinin denetim sürecinde kendilerini geliştirebilecekleri ortamların yaratılması da önemli stratejilerden biri olarak düşünülebilir. Bunun için de akran denetimi önemli bir yöntem olabilir. Bu doğrultuda çalışmanın amacı, matematik öğretmenlerinin akran denetimine ilişkin görüşlerinin belirlenmesidir.

Araştırmanın problemi, "Matematik öğretmenlerinin akran denetimine ilişkin görüşleri nelerdir?" şeklinde belirlenmiştir. Çalışmanın alt problemleri ise "Matematik 
öğretmenlerine göre akran denetimi nasıl olmalıdır?" ve "Matematik öğretmenlerinin akran denetiminin avantaj ve dezavantajlarına yönelik görüşleri nelerdir?” şeklindedir.

\section{Yöntem}

\section{Araştırmanın Modeli}

Matematik öğretmenlerinin akran denetimine ilişkin görüşlerini belirlemeyi amaçlayan bu araştırma, nitel araştırma türlerinden biri olan durum çalışması modelini yansitmaktadır. Durum çalışması gerçek yaşamdan güncel olay veya durumların araştırılmasını içermektedir (Yin, 2009). Sınırları belirlenmiş bir araştırma konusu; doğal ortamında detaylı olarak incelenip, araştırmacı ve katılımcıların bakış açılarıyla biçimlenmektedir. Durum çalışmalarında araştırmacı, katılımcılarla etkileşime girerek belirli bir duruma ya da durumlara odaklanmaktadır (Gall, Gall, \& Borg, 1999). Yin (2003) durum çalışmasını dört türe ayırmaktadır. Bu çalışmada, tek bir durum içinde birden fazla birim ya da alt tabaka olduğu için iç içe geçmiş tek durum çalışmasıdır.

\section{Katılımcilar}

Araştırmada matematik öğretmenlerinin seçilmesinin nedeni, PISA ve TIMSS gibi uluslararası sınavlarda matematik dersinin ve matematiksel düşünme becerilerinin belirleyici olmasıdır. Matematik başarısını arttıran ve matematiksel düşünme becerilerini öğrencilere kazandıran kişiler ise matematik öğretmenleridir. $\mathrm{Bu}$ doğrultuda, araştırmanın katılımcıları daha önce denetmenler tarafından denetim geçirmiş dokuz matematik öğretmenidir. Matematik öğretmenleri amaçlı örnekleme yöntemlerinden maksimum çeşitlilik örnekleme yöntemiyle seçilmişlerdir. Amaçlı örnekleme yöntemi, zengin bilgi içerdiğine inanılan durumların derinlemesine incelenmesine olanak vermektedir (Yıldırım \& Şimşek, 2008). Bu araştırmada, göreli olarak küçük bir katılımcı grup oluşturulmuş ve katılımcı grupta araştırma problemine taraf olabilecek bireylerin çeşitliliğini maksimum derecede sağlamak amaciyla maksimum çeşitlilik örneklemesi kullanılmıştır. Patton'a (1987) göre, maksimum çeşitlilik gösteren araştırma grubu oluşturmanın en az iki yararı vardır. Bunlar, çalışma grubundaki her durumun kendine özgü boyutlarının ayrıntılı olarak tanımlanması ve büyük ölçüde farklılık gösteren durumlar arasında ortaya çıkabilecek ortak kategoriler ve bunların değerinin ortaya çıkarılmasıdır. Bu araştırmada, matematik öğretmenleri Türkiye'nin yedi farklı coğrafi bölgesinden en az bir kişi olacak şekilde seçilerek, genellemeye gidilmek hedeflenmemiş; bunu yerine farklı görüşlerin ortaya çıkması adına çalıştıkları bölge bakımından çeşitlilik sağlanmaya çalışılmıştır. Ayrıca, bu çeşitlilik yaş, cinsiyet ve öğrenim durumları bazında da sağlanmıştır (bkz. Tablo 1). 
Tablo 1

Katılımcılara İlişkin Bilgiler

\begin{tabular}{cccccc}
\hline Kod İsmi & Çalıştı̆ı Bölge & Yaş & Öğrenim Durumu & Cinsiyet & Geçirdiği Denetim Sayısı \\
\hline Ö1 & Doğu Anadolu & 34 & Lisans & Erkek & 3 \\
Ö2 & Ege & 37 & Lisans & Erkek & 3 \\
Ö3 & İç Anadolu & 31 & Yüksek Lisans & Kadın & 2 \\
Ö4 & Karadeniz & 30 & Yüksek Lisans & Kadın & 2 \\
Ö5 & Güneydoğu & 29 & Yüksek Lisans & Kadın & 2 \\
Ö6 & Marmara & 30 & Lisans & Kadın & 2 \\
Ö7 & Akdeniz & 59 & Lisans & Erkek & 6 \\
Ö8 & Ege & 55 & Lisans & Kadın & 5 \\
Ö9 & Marmara & 30 & Yüksek Lisans & Kadın & 2 \\
\hline
\end{tabular}

\section{Veri Toplama Araçları}

Çalışmada matematik öğretmenlerinin akran denetimine ilişkin görüşlerini ortaya koymak amacıyla ilgili literatür taranarak açık uçlu soru tekniğine uygun yarı yapılandırılmış sorulardan oluşan yarı yapılandırılmış görüşme formu hazırlanmıştır. Hazırlanan görüşme formunun geçerlik ve güvenirliğini sağlamak amacıyla; araştırmacılar dışında biri eğitim bilimleri, diğeri matematik eğitimindeki iki öğretim üyesinden uzman görüşü alınmıştır. İki matematik öğretmeniyle pilot çalışma gerçekleştirilmiş ve yarı yapılandırılmış görüşme formu son haline getirilmiştir. Araştırmada, matematik öğretmenlerinin akran denetimine ilişkin görüşlerini ayrıntılı olarak ortaya çıkarmak amacıyla hazırlanan yarı yapılandırılmış görüşme formunda matematik ögretmenlerine yöneltilen temel sorular "Nasıl bir akran denetimi sizleri mutlu eder?, Akran denetiminin avantajları neler olabilir?, Akran denetiminin dezavantajları neler olabilir?, Sınıfınızda akran denetimi uygulamasına bakış açınız ne olur?" şeklindedir.

\section{Veri Toplama Süreci}

Yedi farklı coğrafi bölgedeki 14 matematik öğretmeniyle çalışmayı gerçekleştirmek amacıyla iletişime geçilmiştir. Matematik öğretmenleri, çalışmaya katılmaya gönüllü olanlardan ve çalıştıkları bölge, yaş, cinsiyet ve öğrenim durumları bazında farklılık gösterenlerden seçilmeye çalışılmıştır. Matematik öğretmenleriyle onların uygun zamanlarında bireysel görüşmeler gerçekleştirilmiştir. Seçilen dokuz öğretmenden beş tanesi ses kaydına izin vermiş, dört tanesi ise izin vermemiştir. Ses kaydına izin vermeyen öğretmenlerin cevapları kelimesi kelimesine kâğıda not edilmiş, yazılanlar öğretmenlere okunmuş ve eklemek istedikleri cevaplar kâğıda eklenmiştir. Yapılan görüşmeler ses kaydına izin veren öğretmenlerle yaklaşı 25 dakika, yazılı olarak not edilenlerde yaklaşık 45 dakika sürmüştür.

\section{Verilerin Analizi}

Verilerin analizinde içerik analizinden yararlanılmıştır. Araştırmacılar tarafından ses kayıtları ve not edilen kâğıtlar incelenmiş, her birinin araştırmaya katkı sağlayacak nitelikte olduğuna karar verilmiştir. Veri analizi sürecinde verileri kodlama, kategorileri 
oluşturma, kod-kategorileri düzenleme ve raporlama (Yıldırım \& Şimşek, 2008) adımları izlenmiştir.

$\mathrm{Bu}$ doğrultuda, görüşleri alınan öğretmenler "Ö” harfiyle kodlanmıştır. Doğrudan alıntılarda öğretmen isimlerinin yerine Ö5, Ö7, ... şeklinde kod isimleri kullanılmıştır. İlk aşamada veriler incelenirken araştırmacılar tarafından ayrı ayrı ilkel kodlar oluşturulmuştur. İlkel kodlar üzerinden üç kodlayıcı kodlarını karşılaştırmış ve ortak görüşler doğrultusunda gelişmiş kodlar belirlenmiştir. Kodlayıcılar arasında ortak görüş doğrultusunda uyuşmayan kodlar için iki yol izlenmiştir: ilkel kodlardan en uygun olanı seçerek diğerini çıkarma veya ilkel kodların yerine ortak farklı bir gelişmiş kod yazma. Kodlayıcılar aralarında tartışılarak kodlara ilişkin ortak görüş sağlanmış ve kategorilerin oluşturulması aşamasına geçilmiştir.

Kodlayıcılar yine ayrı ayrı elde edilen ortak gelişmiş kodları ortak özellikleri doğrultusunda gruplandırarak kategorileri ortaya çıkarmıştır. Kodlayıcılar arasında tartışılarak bu süreçte ortak görüş sağlanmış ve iki gelişmiş kategoriyi açıklayan toplam dokuz gelişmiş kod ortaya çıkmıştır.

Üç araştırmacı tarafından analiz edilen verilerin analizi sürecinde, kodlayıcılar arası güvenirlik formülü (Miles \& Huberman, 1994) kullanılmış ve ikili kodlayıcılar arasındaki güvenirlikler alınmıştır. Elde edilen değerlerin ortalaması \%84 olarak hesaplanmıştır. Miles ve Huberman (1994), geçerli bir nitel güvenirlik için, kodlayıcılar arasındaki güvenirliğinin en az \%70 uyumlu olması gerektiğini belirtmektedir. Bu anlamda çalışmada kodlayıcılar arası güvenirliğin iyi düzeyde olduğu görülmüştür. Bunun yanı sıra ortak görüşler doğrultusunda kod-kategorilerin düzenlenmesi ve elde edilen son gelişmiş kod-kategorilere ilişkin iki uzmanın görüşünün alınması ile geçerlikgüvenirlik arttırılmaya çalışmıştır. Elde edilen veriler yorum katılmadan, açık bir şekilde ve doğrudan alıntılarla sunulmuş, daha sonra tartışılmış ve raporlaştırılmıştır.

\section{Bulgular ve Yorumlar}

Matematik öğretmenlerinin akran denetimine ilişkin görüşlerini belirlemek amacıyla gerçekleştirilen çalışmada verilerin analizi sonucunda iki gelişmiş kategori (ön koşul özellikler ve süreç özellikleri) altında dokuz gelişmiş kod ortaya konulmuştur. Ön koşul özellikler kategorisi denetmenin öğretmen olması, fiziksel donanım, bürokratik durumlar alt kategorileri altında; Süreç özellikleri kategorisi ise nesnel denetim, gelişimi destekleme, çözümleyici olma, etkili iletişim, işbirlikli denetim ve güven ortamı alt kategorileri altında incelenmiştir (bkz. Tablo 2). 
Tablo 2

Veri Analizi Sonucunda Elde Edilen Kategori ve Alt Kategoriler

\begin{tabular}{cc}
\hline A. Ön Koşul Özellikler & \multicolumn{1}{c}{ B. Süreç Özellikleri } \\
\hline $\begin{array}{c}\text { A1. Denetmenin Öğretmen Olması } \\
\text { A1.1. Konu Alanı Uzmanı }\end{array}$ & B1. Nesnel Denetim \\
A1.2. Aynı Şartlarda Çalışma & B2. Gelişimi Destekleme \\
A2. Fiziksel Donanım & B2.1. Yetenekleri Ortaya Çıkarma \\
& B2.2. İyi Örnekler Sunma \\
& B2.3. Hataların Farkına Varma ve Ortadan Kaldırma \\
& B2.4. Puanlamanın Olmaması \\
& B3. Çözümleyici Olma \\
B4. Etkili İletişim \\
B4.1. Olumlu/Olumsuz Durumları Açıça Paylaşma \\
B4.2. Denetim Öncesi İletişim Kurma \\
B4.3. Anlayışlı Olma \\
B5. İşbirlikli Denetim \\
B6. Güven Ortamı
\end{tabular}

\section{Ön Koşul Özellikler}

Matematik öğretmenlerinin akran denetimine ilişkin görüşleri incelendiğinde, akran denetiminin bazı ön koşul özelliklere sahip olması gerektiğini ifade ettikleri belirlenmiştir. Matematik öğretmenlerinin görüşlerine göre ön koşul özellikler; denetmenin öğretmen olması, sınıfın fiziksel donanımının eksiksiz olması ve bürokratik durumların eğitime ve denetime engel olmaması şeklinde ortaya çıkmıştır.

Denetmenin öğretmen olması. Matematik öğretmenlerinin görüşleri incelendiğinde, akran denetime ilişkin ön koşul özelliklerden birisi denetmenin öğretmen olmasıdır. Ayrıca, bu gelişmiş kod altında matematik öğretmenleri denetmenin kendi alanlarıyla aynı branştan olmasının ve aynı çalışma koşullarına sahip olması gerekliliğine vurgu yapmışlardır. Ö2 denetim türlerine göre akran denetiminin daha uygun bir denetim yolu olduğunu ifade etmiş ve denetmenin denetlenen ile aynı şartlarda çalışmasının denetimin geçerliliği ve güvenirliğini arttıracak bir faktör olduğunu belirtmiştir. Ö3 ise denetlenenin kendi durumuna en yakın olan ve aynı uzmanlık alanından bir denetmenle gerçekleştireceği paylaşımlarla denetim sürecinde en verimli ortamın sağlanacağını ifade etmiştir.

Ö2: Denetimin yapılacă̆ sınıfta derse giren akranın denetlemesinin daha uygun olacağını düşünüyorum. ...Denetleyen kişi, denetlenen kişiyi bir kez gözlemlemediyse, aynı şartlarda çalışıyorsa denetlemenin geçerliliği ve güvenirliği artabilir.

Ö3: Ama en çok kişinin kendi durumuna en yakın olan aynı uzmanlık alanından birileriyle daha zengin ve kaliteli paylaşımları olur diye düşünüyorum.

Fiziksel donanım. Matematik öğretmenlerinin görüşlerine göre akran denetimine ilişkin ön koşul özelliklerden birisi de okulun ve sınıfın fiziksel donanımın eksiksiz/tam olmasıdır. Öğretmenler eğitim ve öğretim sürecinde dersleri etkili 
anlatabilmek, öğrencileri derse çekebilmek ve denetim sürecini verimli geçirebilmek için uygun fiziksel koşulların sağlanması gerektiğini vurgulamışlardır. Örneğin Ö4, nitelikli bir ders süreci geçirebilmesi için sınıfın fiziksel koşullarının uygun ve gerekli materyallerin eksiksiz olması gerektiğini belirtmiştir. Ö7 ise benzer şekilde denetim için uygun koşulların denetim öncesinde sağlanması gerektiğini ifade etmiştir.

Ö4: Sinıfin fiziksel özelliklerinin iyi olması istediğim gibi bir ders yapmamı sağlamalı. Ders için kullanilacak materyaller tam olmalı.

Ö7: Öğretim materyalleri ve fiziksel imkânlar olmalı. Bazen derslerde aksilikler çıkabiliyor. Teorik bilgilerin yanında uygulamall göstermeleri gerekiyor. Materyallerim hazır olmalı ve uygun bir ortam olmall.

Bürokratik durumlar. Matematik öğretmenlerinin görüşlerine göre akran denetiminin ön koşul özelliklerinden bir diğeri bürokratik durumlardır. Öğretmenler, bürokratik durumların eğitim-öğretim sürecine engel oluşturmaması gerektiğini, asıl yapmaları gereken şeylerin eğitim-öğretim sürecini verimli geçirmek olduğunu, bürokratik durumların kimi zaman kendilerini bu süreçte engellediğini belirtmişlerdir. Örneğin Ö7, denetmenlerin evrakları sürekli kontrol ettiklerini ve evrak çıktılarının hazırlanmasının aşırı kırtasiyecilik olduğunu ifade etmiştir. Benzer şekilde Ö8, denetmenlerin çok fazla evrak istediklerini, bu istenilen evrakların var olmasının öğrenme sürecinin iyi olduğunu göstermediğini ve denetimde evrak konusunda sınırlamaya gidilmesi gerektiğini vurgulamıştır.

Ö7: Denetimde sürekli istedikleri evraklar vardı. Ders işlerken fazla heyecan yoktu, ama evrak istediklerinde sıkıntı oluyordu. Evrak işleri aşırı kırtasiyecilik oluyor.

Ö8: Eğitsel kol, faaliyet raporu gibi bir sürü evrak var. Bazllarl yapılmiyor bile, ama evraklarl oluyor. Derse girmesinde bir sorun yok. Bazı evraklar gereksiz. Yıllık ve günlük planlar olmalı. Onlarl yaparken ögretmen derse hazırlanmış oluyor.

\section{Süreç Özellikleri}

Matematik öğretmenleri akran denetimi sürecinde dikkat edilmesi gereken bazı faktörlerin olması gerektiğini belirtmişlerdir. Matematik öğretmenlerine göre akran denetiminde, süreç boyunca nesnel bir denetim olmalı, öğretmenlerin gelişimi desteklenmeli, denetmeler sorunları çözümleyici olmalı, etkili iletişim kurabilmeli, işbirlikli bir denetim sağlamalı ve bu denetim güven ortamında gerçekleştirilmelidir.

Nesnel denetim. Matematik öğretmenlerinin görüşlerine göre akran denetiminin süreç özelliklerinden biri nesnel denetimdir. Öğretmenler eğitim-öğretim sürecinde kendilerini değerlendirecek olan kişilerin tarafsız olması ve gözlem süreçlerini objektif bir şekilde kendilerine aktarmaları gerektiğini belirtmişlerdir. Örneğin Ö1 yanlı davranırsa, yani yakın arkadaşların birbirlerinin mesleki performanslarını eleştirmeyip, aralarının kötü olduğu öğretmenlerin mesleki performanslarına gerçekte olmadığı kadar olumsuz görüşlerde bulunurlarsa; akran denetiminin istenilen nitelikte olamayacağını ve istenilen güvenilir sonuçlara ulaşılamayacağını belirtmiştir. Ö2, akran denetiminde öğretmenler arasındaki samimiyet düzeyinin önemli olduğunu, denetim sürecine öğretmenlerin duygusal değil, objektif yaklaşmaları gerektiğini vurgulamıştır. Ö9 da Ö2'ye benzer şekilde, duygusal davranılarak değerlendirme yapılmaması gerektiğini, tarafsız bir şekilde ders sürecinin gözlemlenerek öğretmenin mesleki performansı hakkında gerçekçi dönütler verilmesi gerektiğini belirtmiştir. Ö7 ise akran denetiminde 
ciddiyet olması gerektiğini, yakın ilişkilerde ciddiyetsizliğin ortaya çıkabileceğini ifade etmiştir.

Ö1: Arkadaş denetimlerinin dezavantajı olarak ise, aman arkadaşım alınır, bana kirllır düşüncesine kapılarak gördüklerimizi söylememek sistemin olumlu ilerleyişini engeller. Bunun tam tersi, arasının iyi olmadı̆̆ meslektaşının moralini bozabilecek kişilerin katılması da olumsuzluk oluşturabilir.

Ö2: Arkadaş (akran) denetiminde ikili ilişkiler ve denetlenen ile denetleyen arasindaki samimiyet düzeyi denetimi olumsuz etkileyebilir. ...Denetim yaparken objektif olabilmeli. Denetim esnasında duygusallı̆̆ını ön plana çıkarmamalı.

Ö7: Yaklaşım olumlu ve ciddiyet olmall. Arkadaş olunca ciddiyetsizlik olabilir. Disiplinsiz bir durumu ortaya çıkabilir.

Ö9: Ĕ̆er bu kişi kurllır hiç bir şey söylemeyeyim denirse denetimin hiçbir faydası olmaz. Ya da kâğıt üzerinde kalacaksa veya tek bir ders gelip gözlemleyecekse bunun bir faydası olmaz.

Bunun yanında Ö6, müdürlerin yaptıkları denetim sürecinde okul müdürlerinin, müdür-öğretmen ilişkisini ön planda tuttuklarını, yaşanmışlıkları değerlendirme sürecine yansıttıklarını ve bu nedenle tarafsız bir denetim süreci geçirilmediğini belirtmiştir.

Ö6: Müdürler tarafindan denetleniyoruz, ama bu denetimde bazı kişisel görüşlerin veya kişisel yaşanmışlikların denetlemeyi etkilememesi adına müdürlerin de başka kişiler tarafindan ögrretmenlerle konuşularak denetlenmesini önerebilirim. ...Burada kişisel özelliklerin akran değerlendirmeye yansimasinı söyleyebilirim. Denetleme yapacak olan kişinin uzman ve objektif olmaması durumunda denetlemeler bilgi paylaşımından ziyade bir baskıya dönüşebilir.

Gelişimi destekleme. Matematik öğretmenlerine göre akran denetiminin süreç özelliklerinden biri de gelişimi desteklemedir. $\mathrm{Bu}$ kategori altında matematik öğretmenleri denetmenin öğretmenlerin yeteneklerini ortaya çıkaran, iyi örnekler sunan, derslerdeki öğretmen hatalarının farkına vararak bu hataları ortadan kaldırmaya çalışan kişiler olması gerektiğini ve bu süreçte puanlamanın olmaması gerektiğini belirtmişlerdir.

Ö3, akran denetiminde öğretmenlerin güçlü olan yönlerinin tespit edilerek, bu yönlerin eğitim-öğretim sürecine katkıda bulunacak şekilde desteklenmesi gerektiğini belirtmiştir. Ö7, denetmenlerin öğretmenlerin farkına varamadıkları yeteneklerini belirleyip bunları öğretmenlere aktarması gerektiğini söylemiştir. Ö8 ise akran denetiminin olumlu bir uygulama olacağına inandığını, bu uygulama sayesinde kendisini geliştirerek derslere daha donanımlı gelmeye özen göstereceğini ifade etmiştir.

Ö3: Öğretmenin güçlü taraflarından söz etmek zordur. Onun bu yönden desteklenmesi denetimi daha kaliteli yapabilir. ... Denetimci güçlü taraflarımı ortaya çılkararak destek olmalıdır. Böyle birlikte tartışllarak gelişimime katkı sağlayan ortam beni daha mutlu eder.

Ö7: Bize müfettişler 3 yllda bir geliyordu. Bu da bizim gelişimimiz için iyi oluyordu. ...Öğretmen kendini yenilemek ister. ...Denetmen boş boş konuşmamalı bizlere bir şeyler verebilmeli, farkına varamadığımız yeteneklerimizi söylemeli. Biz kendimizi göremiyoruz çünkü. Hangi kısımlarda iyiyiz hangi klsımlarda değiliz bilmiyoruz. Denetmen bunları söylemeli. Sadece eksikleri belirlememeli.

Ö8: Kişi kendisini daha çok gelişstirir. Olumlu olur her anlamda. Araştırma yapar, daha donanımlı girer. Stajyer gelince derse genç öğretmenler kendilerini göstermek için o ders kullanmayacă̆ materyalleri bile kullanabilir.

Ö5, akran denetiminde ders sırasında iyi uygulamalar sergileyen öğretmenlerin bu uygulamalarının kayıt altına alınarak, ihtiyaç duyan öğretmenlerle paylaşılması gerektiğini ifade etmiştir. Ö7, akran denetimi uygulaması sayesinde öğretmenlerin 
akranında gözlemlediği iyi uygulamaları kendi derslerinde uygulama olanağı bulacağını belirtmiştir.

Ö5: Denetimler sonrasında öğretmenlerin eksik oldukları alanları geliştirebilmesi için hizmet içi eğitimler verilebilir. Akran denetiminde olumlu dönütler alan öğretmenlerin dersleri kayıt altına alınip isteyen ögretmenler tarafindan izlenebilir.

Ö7: Akran denetimi aklima gelmeyen şeyler yapmamda bana yol gösterir. Ben akranımı gözlemlemeye gittiğimde onun kullandı̆̆ı iyi uygulamaları gözlemleyip ben de derslerimde bunu uygulayabilirim. Çok da güzel olur.

Ö1, akran denetimi sayesinde ders içerisinde farkına varılmadan yapılan yanlışların branştaşı tarafından uygun bir şekilde öğretmene iletilebileceğini ve bu sayede öğretmenin sonraki ders süreçlerinde bu tür yanlışları yapmamaya özen göstereceğini belirtmiştir. Ö4 benzer şekilde, fark etmeden hata yapılan yerlerin öğretmene bildirilmesinin öğretmenin bu hatalarının önüne geçilmesini sağlayacağını ifade etmiştir. Ö9 da akran denetimi sayesinde yapılan hataların görülerek öğretmene iletilmesiyle ders anlatım sürecinin daha verimli hale getirilebileceğini vurgulamıştır.

Ö1: Bu arkadaş denetimi sayesinde bilmeden yaptığımız yanlışlar var ise bunların farkına varıp uygun çözüm yolları üretebiliriz. ...Ben olumlu yaklaşırım, çünkü ders içinde bilmeden yaptığım bir yanlı̧ var ise zümrem tarafindan belirlenip bana söylenebilir. ...Arada bilmeden yaptığım yanllşlar varsa bunun farkina varmış olurum.

Ö4: Nasıl daha iyi anlatım yapabileceğimize dair veya hata yaptığımı yerlere ve kelimelere yönelik bize bilgi vererek iyileştirmemizi sağlayabilir.

Ö9: Bazen fark etmeden yanlış yaptı̆̆ımız şeyler olabilir. Akranımız bunu görebilir. Bizi kırmadan nasll daha iyi anlatırı bunu, öğrencinin dikkatini çekeriz, daha başarılı ders işleriz bunun için bizi destekleyebilir.

Ö4, akran denetiminde sadece bir dersin gözlemlenmesinin ardından puanlamanın yapılmasının motivasyonu kötü etkilediğini ve bu şekilde bir akran denetimini istemediğini belirtmiştir. Ö5 puan verilerek yapılan denetimlerin öğretmenlerin doğal olmayan bir şekilde ve daha stresli bir ortamda ders işlemelerine neden olacağını söylemiştir. Ö8 de benzer şekilde, amacın puan vermekten ve düşük not vermek için eksik aramaktan ziyade öğretmeni geliştirmeyi sağlamak olması gerektiğini ifade etmiştir.

Ö4: Müdür ve müfettişin yapıcı davranışlarda olmadıklarını gözlemlediğim için ve tek bir dersin dinlenmesinden sonra puan verilecek olmasl sebebiyle kendimi kötü hissettim. Akran denetiminde de bu şekilde olmamall.

Ö5: Okullarda puanlama esasina dayall yapılan denetimlerin sinnfin atmosferini olumsuz etkileyebileceğini düşünüyorum. Sinıf içi uygulamaları değerlendirmek için veya öğretmeni puanlamak için yapılan bir denetimi tercih etmem.

Ö8: Not vermek söz konusu olduğunda daha çok sendika, taraf tutma gibi durumlar ortaya çıkabiliyor. ...Tanıyanlar yanlı davranabilir. Tam tersi açık aramak isteyenler olabilir ve bunu farkl yerlerde anlatabilirler. ...Not kaygısı olmamalı. Temel amaç ögrenmeyi geliştirmek olmall. Bazıları sırf bize düşük not vermek ve eksik aramak için geliyor.

Çözümleyici olma. Matematik öğretmenlerine göre akran denetiminin süreç özelliklerinden bir diğeri de denetmenin çözümleyici olmasıdır. Matematik öğretmenleri denetmenlerin sadece sorunları ortaya koymamalarını, aynı zamanda bu sorunların çözümü için öğretmenlere rehberlik etmeleri gerektiğini belirtmişlerdir. Örneğin Ö3, denetimin öğretmenleri geliştirmesi ve mesleki performanslarına ilişkin varsa sorunlarını çözmesine veya ortadan kaldırmasına yönelik olması gerektiğini ifade etmiştir. Ö8, genç branştaşına kimi zaman ders işleme sürecine yönelik önerilerde 
bulunduğunu, böylece öğretmenin, denetmen karşısında daha stressiz bir denetim geçirdiğini ifade etmiştir. Denetmenlerin de öğretmenlere ders süresini daha verimli kullanmaları adına yönlendirmelerde bulunmaları gerektiğini belirtmiştir. Ö9 ise nöbet sırasında sorunlar yaşadığını ve bu sorunların çözümünde kendisine yardımcı olacak denetmenlere ihtiyaç duyduğunu vurgulamıştır.

Ö3: Denetim sonunda öğretmenin ufkunun açıldlğg bir denetim olmalıdır. Öğretmen umutsuzluğa kapılmamalıdır. Bir şeyi iyi yapamamanın çaresizliği içine düşmemelidir. Öğretmende gelişme isteği uyandıran bir denetim söz konusu olmalıdır. Öğretmenin bir takım sorunlart varsa bunları ortadan kaldırmaya yönelik olmalıdır.

Ö8: Genç bir öğretmen arkadaşım müfettiş geleceği için bende destek istemişti. Ben de ona yol gösterici olup dersi böyle anlat, planlarına bunlarl ekle şunlardan bahset gibi örnekler vermiştim. $O$ da bunları uygulamış ve mutlu olmuştu. Bence denetmenler de bunu yapmall.

Ö9: Ders esnasında okulda nöbetçiyken farklı birçok sorunla karşılaşıyorum. Bazen bu konuda ne yapsam daha doğru olur diye düşünüyorum. Yardıma ihtiyaç duyduğumda bana çözümle sunan bir denetimi tercih ederim.

Etkili iletişim. Matematik öğretmenlerine göre akran denetiminin süreç özelliklerinden birisi de etkili iletişimdir. Bu kategori altında matematik öğretmenleri, denetmenlerin olumlu veya olumsuz durumları açıkça paylaşmaları ve denetim öncesinde öğretmene haber vererek bu konuda daha anlayışlı olmaları gerektiğini ifade etmişlerdir. Ö2, öğretmenlerin eksikliklerini ortaya koymanın yanında olumlu yönlerinin de ifade edildiği bir denetimin daha faydalı olacağını söylemiştir. Ö3 benzer şekilde, denetmenlerin iletişim kurarken sadece zayıf yönlerini vurgulamaması gerektiğini, aynı zamanda olumlu yönlerini de öğretmenlere iletilerek onların bütüncül olarak değerlendirilmesi gerektiğini vurgulamıştır. Ö9 da denetim sürecinin daha iyi olması için denetmenin hem iyi yönlerini hem de kötü yönlerini birlikte belirleyip bunları öğretmene iletmesi gerektiğini söylemiştir.

Ö2: Sadece eksiklerin gözlendiği bir denetim yerine olumlu yönlerimin de ortaya konulduğu bir denetim daha çok hoşuma gider.

Ö3: Baskl durumundan slyrlmak için denetmenin iletişim becerilerinin çok güçlü olması gerektiğini düşünüyorum ve öğretmenin sadece zaylf yönlerini değerlendiren değil aynı zamanda güçlü yönlerine vurgu yaparak onu bütünsel olarak değerlendirmelidir.

Ö9: Beni eleştirebilir denetmen ama sadece eleştiriyorsa o zaman çok da iyi hissetmem. Bak şunları çok iyi yaptın ama şunları daha iyi yapabilirsin diyebilir. Böyle bir denetim daha iyi olur.

Ö4, geçirdiği birkaç müfettiş denetiminde, denetim öncesinde kendisine haber verilmediği için huzursuzluk yaşadığını ifade etmiştir. Ö9 ise benzer şekilde, denetim öncesinde öğretmene haber verilmesi gerektiğini; gerekli evrakları hazır bulundurabilmesi ve öğrencileri denetmenin geleceği konusunda bilgilendirebilmesi için onlara denetim ile ilgili öncesinde haber verilmesinin önemli olduğunu belirtmiştir.

Ö4: Okul müdürü ve müfettis tarafindan denetlendim. Her ikisi de haberim olmadan ben sinıfa girdiğimde sinıfta bulunduklart için öğrencilerime nasıl bir açılama yapmam gerektiği konusunda kararsız kaldım. Sinıfin bir anda doğası bozulduğu için rahatsı oldum. Ciddi bir şekilde sürekli not aldıkları için de sürekli hata yaptı̆̆gmı düşünerek anlattığım konuya odaklanamadım. Dersin sonunda müfettiş tarafindan bazı hususlar ile ilgili uyarıldım. Müdür ise hiç bilgi vermedi.

Ö9: Denetim yapılmalı tabii ki fakat bana önceden haber verilmeli. Ben evraklarımın bazılarını evde birakiyorum kimi zaman incelemek için. Bir de sinıfta pat diye bir denetmeni görünce heyecan da yaparım hem de hazırlksız yakalanırım. Şu ana kadar olan denetimlerimde haber vermeden gelen müfettiş olmadl. 
Ö3, akran denetiminde denetmenlerin ve denetlenen kişilerin birbirlerine karş1 anlayışlı olmaları gerektiğini belirtmiştir. Ö6 denetmenin tavrının ders işleme sürecini etkileyeceğini söylemiştir. Ö8 ise, denetmenler anlayışlı olduklarında rahat bir şekilde sorularını sorabildiğini ifade etmiştir.

Ö3: Uyumsuzluk her zaman vardır. Öğretmen ve akran denetimi için gelen kişinin birbirlerine karşı anlayışlı olması gerekir. ...Otoritenin olduğu durumlar korkuyu beraberinde getirir dolayısıly doğallık azalır.

Ö6: Denetleyen kişi kesinlikle anlayışlı ve hoşgörülü olmalı. ...Sadece bir müfettiş denetiminde müfettişin tavrından dolayı ders sonuna kadar çok gergindim.

Ö8: Denetmen hoşgörülü olmall. Bu sayede soru sorabiliyorum rahat ve anlayışl olunca. Aklima takılanlarl sorabiliyorum.

İşbirlikli denetim. Matematik öğretmenlerinin görüşlerine göre, akran denetiminde süreç özelliklerinden birisi de işbirlikli denetimdir. Öğretmenler denetmenlerin kendileriyle işbirliği içinde olmaları gerektiğini ve bunun her iki öğretmenin de mesleki performansını arttıracağını belirtmişlerdir. Örneğin Ö4, akran denetimi sürecinde birlikte çalışmanın her iki öğretmenin de mesleki performanslarının artmasına yardımcı olacağını belirtmiştir. Ö5 performansı gözlenen kişinin süreci daha verimli geçirmek amaciyla çaba sarf edeceğini, gözlem yapan kişinin ise gözlediği öğretmenin iyi bulduğu uygulamalarını kendi ders işleme sürecinde kullanabileceğini söylemiştir. Ö7 ise akran denetiminde kişilerin daha stressiz bir ortamda branştaşlarıyla daha zengin ve nitelikli paylaşımları olacağını ve bu şekilde akran denetiminin öğretmenler arasında etkili bir dayanışma sağlayacağını vurgulamıştır.

Ö4: Akran denetimi ile "Daha iyi nasıl bir ögretim yapabilirim?” sorusuna beraber yanıt arayabiliriz.

Ö5: Öncelikle denetim geçiren kişi sınıf içi uygulamalarını daha iyi planlar, süreci nasıl yöneteceğine daha çok dikkat eder. Kendisini geliştirmek için çaba gösterir. Denetim yapan kişi de meslektaşının uygulamalarını gözlemleme firsatı elde eder. Beğendiği bir uygulamayı kendi derslerinde de uygulayabilir. Eksik bulduğu noktalar varsa onlar hakkında fikrini belirtip meslektaşının uygulamalarını geliştirmesine katkıda bulunabilir.

Ö7: Akran denetiminde fikir alışverişinde bulunabilirler ve daha stressiz bir ortamda bulunurlar. ... Daha güzel fikir alabilirim. Benim branştaşım var onunla konuşuyoruz. O benden küçük ama eminim benden bir şeyler öğreniyordur. Ben de ondan bir şeyler öğreniyorum. Yeni mezunlar farklı tekniklerle bir şeyler ögreniyor. Bana da bu açıdan fikir verecektir. Bir taraftan tecrübe de önemli oluyor.

Güven ortamı. Matematik öğretmenlerinin görüşlerine göre akran denetimindeki süreç özelliklerinden bir başkası da güven ortamıdır. Bu kategori altında matematik öğretmenleri; güvenilir olduğuna inanılan bir ortamda denetimin yapılmas1 gerektiğini belirtmişlerdir. Örneğin Ö2, öğretmenlere puan vererek onlar1 karşılaştırmanın eğitim-öğretim sürecini engelleyici bir rekabet yaratabileceğini ve öğretmenler arasındaki ilişkilerde bozulmalara yol açabileceğini ifade etmiştir. Ö8 ise, öğretmenlerin karşılaştırıldığı durumların öğretmenlerin moral ve motivasyonlarını olumsuz etkileyebileceğini ve güven ortamını zedeleyebileceğini vurgulamıştır.

Ö2: Şayet akran denetimleri sonucunda puan verilmesi durumunda bu durum karşılıklı rekabeti düşündüğümüz noktada olumsuz sonuçlar doğuracaktır. ... Böyle durumlarda yaşanan rekabet veya arkadaşlı ilişkileri puanlamaları olumsuz etkileyebilir.

Ö8: Bak bu ögretmen böyle yapıyor sen yapmıyorsun şeklinde olmamalı bu denetimler. O zaman ögretmenin morali de bozulabilir. Bu da güveni zedeler. 
Ö3 akran denetiminde, denetmenlerin ve denetlenen kişilerin birbirlerine güvendikleri bir ortamın oluşturulması gerektiğini ifade etmiştir. Ö2 ise prosedürler ve evrakların ön planda olduğu bir denetimin verimli sonuçlar ortaya koymadığını ve denetimin bazen sadece evrakların ve prosedürlerin kâğıt üzerinde yapıldığını belirterek bu durumun da denetimin güvenilirliğini olumsuz etkilediğini söylemiştir.

Ö3: Akran denetiminde güven ortamında oluşan bir gözlem olmalıdır.

Ö2: Mevcut denetim sisteminde prosedürler daha ön plana çıkmaktadır. Bu da denetimin geçerliliğinde sorun oluşturmaktadır. ...Denetim sadece prosedürlerin yerine getirildiği ve evrakların ön plana çıktı̆̆ı bir süreç olmamalıdır.

\section{Sonuç, Tartışma ve Öneriler}

Matematik öğretmenlerinin akran denetimine ilişkin görüşlerini belirlemek amacıyla gerçekleştirilen çalışmada, verilerin analizi sonucunda iki temel kategori (ön koşul özellikler ve süreç özellikleri) altında dokuz alt kategori ortaya çıkmıştır. Ön koşul özellikler temel kategorisi denetmenin öğretmen olması, fiziksel donanım, bürokratik durumlar kategorileri ile şekillenmiştir. Süreç özellikleri temel kategorisi ise nesnel denetim, gelişim destekleme, çözümleyici olma, etkili iletişim, işbirlikli denetim ve güven ortamı kategorileri ile şekillenmiştir.

Matematik öğretmenleri denetmenlerin öğretmen olması gerektiğini vurgulamışlardır. Yurdakul ve Tok (2017) çalışmalarında; denetmenlerin hem rehberlik hem de soruşturma görevlerinin birlikte olmasının denetmenleri rahatsız ettiğini, onların kendilerine olumsuz tavır aldıklarını hissettiklerini ve bu nedenle rehberlik yapmakta zorlandıklarını ifade etmiştir. Yıldırım (2009) ise çalışmasında; denetmenlerin soruşturma görevinin, denetmen-öğretmen iletişimini olumsuz etkilediğini vurgulamıştır. Bu anlamda soruşturma görevleri denetmenler tarafından yürütülürken; rehberlik görevleri akran denetiminde görevli öğretmenler tarafından yürütülebilir. Denetmen-öğretmen ilişkisinde bir hiyerarşi bulunmaktadır. Ayrıca denetmenler ve şu anda ders denetimi görevini üstlenen müdürler; iş yükleri nedeniyle öğretmenlere mesleki anlamda rehberlik yapma konusunda zaman sıkıntısı yaşayabilmektedirler. Bozak (2014) çalışmasında akran denetimi uygulamasına katılan öğretmenlerin tamamının uygulama hakkında olumlu görüş bildirdiklerini ifade etmiştir. Bu nedenle denetimde alternatif bir yöntem olarak akran denetimin uygulanabileceği düşünülmektedir.

Matematik öğretmenleri denetmenin kendileriyle aynı branştan olmasının gerekliliğini vurgulamışlardır. Tonbul ve Baysülen (2017) çalışmalarında, müdürlerin etkili bir denetim yapamamalarının önündeki engeller arasında branşlar arasındaki farklılıkların bilgisine sahip olamamalarını göstermiştir. Akran denetimi sayesinde aynı branş gruplarının kendi aralarında sinerji yaratarak; daha etkili ve verimli öğrenme ortamları yaratabilecekleri söylenebilir.

Matematik öğretmenleri denetmenin aynı çalışma koşullarına sahip olması gerekliliğine vurgulamışlardır. Bozak'ın (2014) çalışmasında öğretmenler, akran denetiminin şu anki sistemde uygulanmakta olan rehberlik çalışmalarına göre daha etkili olacağını belirtmişlerdir. Bu durumun nedeni olarak da öğretmenler; aynı zümrede ve aynı çalışma koşullarına sahip olan meslektaşlarının kendilerini daha iyi anlayabileceklerini, öyle bir ortamda daha rahat hissedeceklerini belirtmişlerdir. Ayrıca Bozak'ın (2014) çalışmasında öğretmenler, denetmenlerin kısa süreli gözlemlerinin 
doğru değerlendirme yapmaları için yeterli olmadığını ifade ettikleri görülmüştür. Matematik öğretmenlerinin denetmenlerin etkili karar alabilmeleri için örgüt iklimlerinin anlaşılması gerektiğine bu nedenle de aynı çalışma koşullarına sahip olunması gerektiğine inandıkları düşünülmektedir. Okulların bulundukları çevre, fiziksel koşulların uygunluğu, öğrenci başarı durumları, veli profilleri gibi pek çok faktörün denetmenler tarafından göz önünde bulundurulması önerilmektedir.

Matematik öğretmenleri denetimin öncesinde uygun fiziksel koşulların hazır olması gerektiğini belirtmişlerdir. Topçuoğlu (2015) çalışmasında öğretmenlerin, mesleki performanslarını sergileyebilmelerinin ve mesleki gelişimlerini sağlayabilmelerinin koşulu olarak, fiziksel ortamların düzenlenmesinin gerektiğini ifade etmiştir. Matematik öğretmenleri bilgisayar, akıllı tahta, projeksiyon gibi teknolojik araçlar ve farklı yazılımlar kullanarak ders etkinlikleri tasarlayabilmektedirler. Denetim için bu tür fiziksel koşullar sağlanmalı ve öğretmenlerin kullanımına hazır olmalıdır.

Matematik öğretmenleri, bürokratik durumların eğitim-öğretim sürecine engel oluşturmaması gerektiğini belirtmişlerdir. Memduhoğlu (2012) çalışmasında denetimlerde daha çok evrak, plan, dosya, defter gibi biçimsel konulara ağırlık verildiğini ifade etmiştir. Ayrıca, bu tür kontrol odaklı denetimlerin öğretmenlerin, eksik ve yanlışlarını gizlemeye yönelteceğine ve böylece öğretmenlerin gelişimlerinin engelleneceğine değinmiştir. Kazak (2013) da çalışmasında denetmenlerin daha çok evraklarla ilgilendiğini, ders gözlemini arka plana attığını belirtmiştir. Yağmur (2018) ise ders denetiminin evrak kontrolünden öteye gidemediği sonucuna ulaşmıştır. Akran denetimi sayesinde bu tür bürokratik durumlar yerine öğretmenlerin eğitim-öğretim faaliyetleri süreçte öne çıkarılabilir.

Matematik öğretmenleri denetimin bazı özelliklerinin süreç boyunca olması gerektiğini belirtmişlerdir. Denetimin süreç boyutunda; nesnel denetim, gelişimi destekleme, çözümleyici olma, etkili iletişim, işbirlikli denetim ve güven ortamı kategorileri elde edilmiştir. Başar (1988) ise çalışmasında denetimin dört boyutundan birinin süreç boyutu olduğunu ifade ederek bu boyutun durum saptama, önerilerde bulunma, değerlendirme ve geliştirmeden oluştuğunu ortaya koymuştur. Denetim bir sistem olduğuna göre, sistem yaklaşımı gereği denetim girdi, çıktı, süreç ve dönütlerden oluşmaktadır. $\mathrm{Bu}$ anlamda matematik öğretmenleri denetimin nesnelliğinin, öğretmen gelişimi desteklemesinin, çözüm bulmasının, etkili iletişimin, işbirlikli olmasının ve güven duyularak yapılmasının süreç boyunca olmasını istediklerini ifade etmişlerdir.

Matematik öğretmenleri denetmenlerin tarafsız olması gerektiğini belirtmişlerdir. Tonbul ve Baysülen (2017) çalışmalarında; öğretmenlerin, kendilerini değerlendirecek kişiler için objektif değerlendirme araçları oluşturulması gerektiğini ifade ettiklerini belirtmiştir. Straughter (2001) çalışmasında; akran denetimine katılan öğretmenlerin, hassas ve kırılgan olmaları ve meslektaşlarını eleştirmekten çekinmeleri nedeniyle nesnel bir denetim yapılamayabileceğini ve bunun akran denetim süreci için olumsuz bir durum olduğunu belirtmiştir. Akran denetimindeki en öne çıkan problem nesnel bir denetimin sağlanıp sağlanamayacağı sorunu olarak ortaya çıkmıştır. Bu anlamda asıl amacin öğretmen gelişim olduğu vurgulanıp, bu sürecin öğretmenlerin yararlarına olduğu bilinci öğretmenlere kazandırılabilir. Ayrıca, öğretmenlere eksiklikleri belirlenen alanlarda hizmet içi kurslar açılıp bu eksiklikleri yaşayan öğretmenlerle birlikte kapatabilecekleri işbirlikli çalışma ortamları yaratılabilir. 
Matematik öğretmenleri denetimin gelişimlerini desteklemesi gerektiğini belirtmişlerdir. Karagözoğlu (1977), öğretmenlerin denetim sürecinde eğitim-öğretim etkinliklerini planlama ve yürütme konusunda yeterince destek alamadıkları sonucuna ulaşmıştır. Tonbul ve Baysülen (2017) çalışmalarında oldukça az sayıdaki müdürün ders denetimi yaptığını ve bu denetimlerin öğretmenlerin mesleki gelişimine yansımadığını belirtmişlerdir. Yurdakul ve Tok (2017) çalışmalarında denetmenlerin; öğretmenlerin gelişimlerini destekleyici yönde rehberlik etme görevini yeterince yerine getiremediklerini düşündüklerini ortaya koymuşlardır. Bu durumun nedeni olarak ise; denetmenlerin ders denetimi yapmadıkları için öğretmenle birebir iletişim kuramamalarını göstermişlerdir. Bu araştırmalar doğrultusunda; denetmen ya da müdür tarafından yapılan denetimlerin, öğretmenlerin mesleki gelişimlerini istenilen düzeyde arttırmadığ 1 söylenebilir. Akran denetimi uygulamalarında ise farklı bir durum söz konusudur. Örneğin Bozak (2014) çalışmasında; akran denetimine katılan öğretmenlerin, birbirlerine mesleki anlamda gelişmelerini sağlayan dönütler verdiklerini ve birbirlerine yeni öğretim yöntem ve teknikleri öğrettiklerini ifade etmiştir. Bauer’in (1987) deneysel çalışmasında ise akran denetiminde; öğretmenlerin ders gözlemi yapma süreleri arttıkça, uygulamaya ilişkin algıların olumlu yönde değiştiği bulunmuştur. Akran denetimi uygulamaları okullarda gönüllü öğretmenler tarafından uygulanmaya başlayabilir. Öğretmenlerin gelişimleri ve bu uygulamadan memnuniyetleri arttıkça, bu uygulamaya olan istekliliğin artacağı düşünülmektedir.

Matematik öğretmenleri denetmenin öğretmenlerin yeteneklerini ortaya çıkaran kişiler olması gerektiğini belirtmişlerdir. Memduhoğlu (2012) çalışmasında denetmenlerin; öğretmenlerin "neleri yaptığını" ortaya koyduklarını, fakat "neleri yapabileceklerini" ortaya koymayı ihmal ettiklerini belirtmiştir. Alternatif bir denetim yöntemi olan akran denetimi için Bozak (2014) çalışmasında; akran denetiminin mesleki öz-farkındalıklarını arttırdığını, böylece öğretmenlerin kendi olumlu yönlerini görerek motive olduklarını belirtmiştir. Ayrıca, akran denetimi sayesinde öğretmenlerin, eğitim-öğretim sürecinde yaşadıkları olumsuzluklara ilişkin öğretmen arkadaşıyla birlikte çözümler arayarak, özgüvenlerini arttırıcı bir rol oynadığını ifade etmiştir. Akran denetimi uygulamasıyla öğretmenlerin birbirlerinin güçlü yönlerini ortaya koyduklarını ve kendi yeteneklerinin de farkına varmalarını sağlaması nedeniyle yararlı bir uygulama olduğu düşünülmektedir. Bu nedenle, akran denetimi ile farklı yeteneklere sahip öğretmenler bir araya getirilerek zengin eğitim-öğretim ortamları oluşturulması sağlanabilir. Günümüzde Koehler ve Mishra'nın (2005) ifade ettiği teknolojik pedagojik alan bilgisi iyi düzeyde öğretmenlerin yetiştirilmesi hedeflenmektedir. Burada üç temel boyut pedagoji bilgisi, alan bilgisi ve teknoloji bilgisidir. İki öğretmen seçilirken biri teknoloji bilgisi iyi düzeyde diğeri ise pedagoji bilgisi iyi düzeyde olacak şekilde öğretmenler belirlenirse; birbirlerinin iyi oldukları noktalarda diğer öğretmene destek sağlayarak birbirlerini geliştirecekleri ve aynı zamanda da değerli olduklarını hissedecekleri etkili bir işbirlikli ortam sağlanabilir.

Matematik öğretmenleri denetmenin iyi örnekler sunan kişiler olması gerektiğini belirtmişlerdir. Marks, Stoops ve King (1971) çalışmasında denetmenler deneyimlerden yararlanmak için örnek olay ve sonuçların kaydedilmesi gerektiğini belirtmiştir. Fullerton (1999) akran denetiminin; örnek uygulamaları ve uygulayıcıları iş başında görme olanağı sağladığını ifade etmiştir. Akran denetimi uygulaması okullarda zümre öğretmenleri tarafından uygulanıp iyi örneklerin kendi aralarında paylaşılması ile 
başlanabilir. İleriki aşamada ilçede bulunan zümre öğretmenler kurulu toplantıları yapılarak iyi olan uygulamalar öğretmenlere iletilebilir ve bu uygulamalar üzerine tartışmalar gerçekleştirilebilir.

Matematik öğretmenleri denetmenin derslerdeki öğretmen hataların farkına varıp bu hataları ortadan kaldırmaya çalışan kişiler olması gerektiğini belirtmişlerdir. Denetmen-öğretmen iletişimini arttırma yollarından biri de Johari penceresidir. Bu pencere dört alandan oluşmaktadır. Bu alanlar; açık, saklı, kör ve bilinmeyendir. Farkına varamadığımız fakat diğer kişiler tarafından görülen alan kör alandır. Denetmenler bu kör alandaki öğretmen hatalarını ortaya çıkarırlarsa, öğretmenler kim oldukları gerçeğini test edebilecek ve kendilerini gelişime açacaklardır (Gümüş ve Gümüş, 2016). Akran denetimi uygulamasıyla yeterli süreyi bir arada geçiren öğretmenler, birbirlerinin farkına varamadıkları hataları gözlemleyecek ve bunları ortaya koyacaklardır. Öğretmenler ortaya konan hataları çözümleyebilmeleri için kibar bir dille uyarılarda bulunulabilir, akran denetimindeki denetmenin deneyimlerinden faydalanılabilir, farklı akran gruplarıyla belirlenen sorun üzerine nitelikli tartışma ortamları yaratılabilir ve bu hatalar ortadan kaldırılmaya çalışılabilir.

Matematik öğretmenleri denetim sürecinde puanlamanın olmaması gerektiğini belirtmişlerdir. Kurban ve Tok (2018) çalışmalarında, performans değerlendirmede okul müdürlerinin arkadaş çevrelerindeki veya aynı sendikada bulundukları öğretmenlere yüksek puanlar verebileceklerini, bu durumun diğer öğretmenler üzerinde moral ve motivasyon düşüklüğüne neden olabileceğini belirtmişlerdir. Akran denetimi uygulamasında öğretmen açısından amaç yüksek ya da düşük puan almak değildir, denetmen açısından bakıldığında da gözlem yaptığı öğretmeni puanlamak değildir; asıl amaç her iki öğretmen için de daha iyi bir mesleki gelişim sağlamak ve eğitim-öğretim sürecini daha nitelikli hale getirmektir. Bozak (2014) çalışmasında akran denetiminde öğretmenlerin; not alma, puan verme durumları söz konusu olmadığı için, mevcut denetim uygulamalarına göre daha etkili bir denetim olarak gördüklerini ifade ettiklerini belirtmiştir. Akran denetim uygulamalarının özündeki bu mantık öğretmenlere aktarılıp bu uygulamayı kendi okullarında hayata geçirmeleri konusunda teşvik edilebilirler.

Matematik öğretmenleri denetmenlerin çözümleyici olmaları gerektiğini belirtmişlerdir. Balcı (2007) çalışmasında, öğretmenlerin denetmenlere karşı olumsuz tutum geliştirmelerindeki etkili faktörlerden birinin öğretmenlerin problemlerine çözüm bulmaya çalışmamaları ve sorgulayıcı bir tavır sergilemeleri olarak belirtmiştir. Memduhoğlu (2012) çalışmasında; denetmenlerin, hata ve eksiklikleri gidermek için çözüm üretmek yerine genel durumu rapor etmekle yetindiklerini belirtmiştir. Topçuoğlu (2015) tezinde, yapılan denetimlerin geçerlilik kazanması için kağıt üzerinde kalmaması gerektiğini, çözüm odaklı denetimler yapılması gerektiğini ifade etmiştir. Bu araştırmalar doğrultusunda şu anki denetim uygulamalarının var olan durumu ortaya koyduğu fakat sorunlara çözüm üretemediği söylenebilir. Taymaz'a (2005) göre denetmenlerin sahip olmaları gereken karar yeterliği, insancıl yeterlik ve teknik yeterlik olmak üzere üç yeterlik bulunmaktadır. Denetmenlerin sahip olması gereken özellikler arasında amaçları gerçekleştirmek için yapılacak işlem basamaklarını tasarlamak, karşılaşılan sorunlara çözüm yolları bulmak ve amaçlara ne derece ulaşıldığına ilişkin karar verme süreci karar verme yeterliği içerisinde yer almaktadır (Taymaz, 2005). Denetmenlerde bulunması beklenen çözümleyici olmanın akran denetimi uygulamasında gerçeklik bulacağı düşünülmektedir. Çünkü akran denetiminin asıl 
amac1 öğretmenin mesleki gelişimidir. Bu süreçte ortaya çıkan sorunlar yine bu akran denetim grupları tarafından çözümlenmeye çalışılacaktır. Akran denetiminde öğretmenler tarafından ortaya konulmuş ve akran denetim grubuyla birlikte çözüm bulunmuş uygulamalar kayıt edilebilir, okul/ilçe zümre toplantılarında diğer öğretmenlerle ve akran denetim gruplarıyla paylaşılabilir.

Matematik öğretmenleri denetmenlerin etkili iletişim kurmaları gerektiğini belirtmişlerdir. Göksoy ve Aslanargun (2014) çalışmalarında, eğitim denetmenlerinde olması gereken nitelikler arasında iletişim becerisi olduğunu ve denetmenlerinin başarısının sahip oldukları bilgi, tecrübe ve yeteneklerden çok, kurdukları insan ilişkilerine bağlı olduğunu belirtmişlerdir. Sistemlerin sağlıklı ve sürekli işleyebilmesi için; bu sistem ile ilgili dönüt sağlayan, düzeltme ve geliştirme amaciyla çabalayan denetim hizmetleri sunulmalıdır (Memduhoğlu, 2012). Bu hizmetler sunulurken iletişim becerisinin önemli olduğu düşünülmektedir. Bozak'ın (2014) çalışmasında öğretmenler, gözlem öncesi ve sonrası görüşmelerde kullanılan dilin yani üslubun önemli olduğunu ve olumsuz yönler öğretmene açıklanırken bile karşıdaki öğretmeni kırmadan, kibar bir dil kullanılması gerektiğini belirtmişlerdir. Akran denetimi uygulamaları için öğretmenlere iletişim yetenekleri güçlendirici hizmet içi eğitimler verilebilir. Bu süreçte okul rehber öğretmenleri kimi zaman akran denetim gruplarına davet edilebilir ve iletişim sürecini güçlendirmek için onların fikirlerine başvurulabilir.

Matematik öğretmenleri denetmenlerin hem olumlu hem de olumsuz durumlart açıkça paylaşılması gerektiğini belirtmişlerdir. Öğretmenlerin denetmenlere yönelik olumsuz algilara sahip olmasındaki etkenlerden biri, rehberlik etme sürecinde kusurlara odaklanmalarıdır (Ünal, 2010; Yıldırım, 2012). Oysa bir denetmenin sadece kusurları ortaya çıkarması öğretmende eksiklik duygusu yaratabilecektir. Akran denetiminin olumlu yanı öğretmenlerin sadece kusurlarını tespit etmek için gözlem yapmamalarıdır. Akran denetiminde öğretmenlerin hem güçlü hem de zayıf yanları birlikte ele alınıp tartışılmaktadır. Olumsuz bir bulgu olarak Potter (1991) çalışmasında akran denetimine katılan öğretmenlerin sadece olumlu hususlar hakkında birbirlerine dönüt verdiklerini, olumsuz hususlar hakkında eleştirisel önerilerde bulunmadıklarını ifade etmiştir. Öğretmenlere olumlu ve olumsuz buldukları durumları birlikte ele alabilecekleri ve bunları öğretmenlere uygun bir şekilde aktarabilecekleri bir bakış açısı kazandırılmaya çalışılabilir. Bunun için yine akran denetiminin asıl amacı olan her iki tarafın da mesleki gelişimi; denetleyen ve denetlenen öğretmen tarafından kavranmalıdır.

Matematik öğretmenleri denetmenlerin denetim öncesinde ögretmenle görüşülmesi gerektiğini belirtmişlerdir. Denetim öncesinde öğretmenle görüşülmesinin en önemli özelliği odaklanılacak konuların öğretmene birlikte konuşulup belirlenmesidir. $\mathrm{Bu}$ süreçte denetmen, hangi veri toplama araçlarını kullanacağını ve hangi somut verileri toplayacağını öğretmene aktarmaktadır. Denetim öncesi görüşme sayesinde öğretmen ve denetmen arasında güven ortamı oluşturmak için gerekli firsat ve zaman sağlanır ve aralarındaki dayanışma güçlendirilmektedir (Gümüş \& Gümüş, 2016). Denetim öncesinde öğretmenle görüşülebilir, akran denetimi sayesinde daha doğal denetim süreçleri yaratılabilir.

Matematik öğretmenleri denetmenlerin anlayışlı olmaları gerektiğini belirtmişlerdir. Taymaz'a (2005) göre anlayışlı olma, etkili çalışma ve ortak bir çaba oluşturabilme için denetmenlerin sahip olması gereken insancıl yeterliklerdendir. Gürsoy ve Aslanargun (2014), eğitim denetmenlerinin sahip olması gereken kişisel 
özellikler arasında anlayışlı, hoşgörülü olma ve empati kurmanın bulunduğunu belirtmiştir. Tok (2015) çalışmasında, öğretmenlerin büyük bir çoğunluğunun denetmenlere ilişkin olumsuz metaforlara sahip olduğunu ve öğretmenlerin en fazla "bunaltan müfettiş" temasıyla metafor ürettiklerini bulmuştur. Yurt dışındaki bazı çalışmalarda da benzer şekilde sonuçlar elde edilmiştir; öğretmenler denetlenmekten kaçmadıklarını fakat denetleyenlerin tutumlarını hoş bulmadıklarını belirtmişlerdir (Acheson \& Gall, 1997; UNESCO, 2007). Akran denetim grupları birbirlerine karş1 anlayışıı olmalarını sağlamak adına insan ilişkileriyle ilgili hizmet içi eğitimler alabilirler.

Matematik öğretmenleri denetmenin kendileriyle işbirliği içinde olması gerektiğini belirtmişlerdir. Uyanık (2007) da benzer şekilde, çağdaş denetimin öğretmen-denetmen işbirliği gerektirdiğini; denetmenlerin bu yönde davranışlar geliştirmeleri gerektiğini belirtmiştir. Göksoy ve Aslanargun (2014) ise; "denetim” yerine "işbirliği" sözcüğünün kullanılmasının daha doğru olduğunu belirtmişlerdir. Senge'in "Beşinci Disiplinde" ifade ettiği üzere öğretmenler, öğrenen okul anlayışı içerisinde, geleneksel denetim anlayışından sıyrılıp, birlikte öğrenme doğrultusunda ders denetimlerini yapılandırmalıdırlar (Tonbul \& Baysülen, 2017). Bu ortamı sağlayan en uygun alternatif yaklaşımın akran denetimi olduğu düşünülmektedir. Bowers (1999), akran denetiminin katılımcılar arasındaki birlikteliği arttırdığını ifade etmiştir. Nelson (2000) ise; akran denetiminin, katılımcıların bireysel öğrenme becerilerini arttırdığını ve işbirlikli öğrenme ortamları yarattığını belirtmiştir. Hirsch (2011), akran denetimi esnasında öğretmenlerin özellikle sınıf yönetimi konusunda deneyim kazandığını ve bu uygulamanın öğretmenler arasında işbirliği ve yardımlaşmayı arttırdığını ifade etmiştir. Akran denetim uygulamaları öğretmenler arasında sinerji yaratılması açısından önemlidir. 21.yüzyıl becerilerinden birinin de işbirlikli çalışma olduğu düşünüldüğünde, öğretmenler birlikte çalışabilecekleri bu tür uygulamalar konusunda teşvik edilebilir. Bu tür uygulamalara gönüllü olan öğretmenleri teşvik etmek amacıyla bu öğretmenlerin ders programlarında ders gözlemleri için uygun saatler oluşturulabilir ya da gözlem yapacağı öğretmenle birlikte girdikleri ders için bir takım ücretlendirmeler yapılabilir.

Matematik öğretmenleri; denetime inanılan bir ortamda denetimin yapılması gerektiğini belirtmişlerdir. Memduhoğlu (2012) çalışmasında; denetmenler ile öğretmenler arasında güven ve iletişim sorunu olduğunu ve her iki tarafın da bunun sorumlusu olarak karşı tarafı gösterdiğini belirtmiştir. Keskinkılıç'ın (1997) çalışmasında; öğretmenler, denetmenleri öğretmene güvenmeyen ve katı davranışlar sergileyen kişiler olarak tanımlamışlardır. Baskı ve korku olan bir ortamda öğretmenlerin sorularını ve sorunlarını denetmenlere aktaramayacağı ve mesleki anlamda gelişmelerinin sağlanamayacağı düşünülmektedir. Straughter (2001), akran denetiminde öğretmenlerin meslektaşlarına daha fazla güven duyduklarını belirtmiştir. Şu anki mevcut uygulamalarda da denetmenler; öğretmenlere güvendiklerini hissettirebilir, mesleki gelişimleri adına onları cesaretlendirebilirler.

Matematik öğretmenleri akran denetimi uygulamasının sınıflarında yapılmasına olumlu yaklaşmışlardır. Bozak'ın (2014) çalışmasında da akran denetimi yöntemini uygulayan 16 öğretmenin tamamının bu uygulamaya olumlu yaklaştığını belirtilmiştir. Akran denetimi uygulamasına öğretmenler olumlu yaklaşmayabilirler, çünkü (i)öğretmenlerin zaman sıkıntıları bulunmaktadır, (ii)meslektaşlarının sınıflarına girmelerine bazen isteksiz davranabilmektedirler, (iii)akran denetiminde herhangi bir 
fayda göremeyebilirler (Richards \& Lockhart, 2007). Fakat; akran denetiminin doğas1 ve amacı açık ve net bir şekilde öğretmenlere iletildiğinde ve gönüllü öğretmenlerin elde ettiği faydaları diğer öğretmenlerle paylaştıklarında bu uygulamaya istekliliğin artacağ düşünülmektedir. 


\section{Summary}

Purpose and Significance: Teachers face with many environmental challenges such as inadequate resources, difficult professional duties, inexplicable expectations, tendency to believe that novice teachers should be tested through tough experiences in their first teaching years (Apaydın, 2014). Despite all these difficulties, they have to show their performances that they are expected to perform. One of the most important aspects of supervision is assessing teacher performances (Aydın, 2016). Supervision is the process of comparing existing practices in the education system, determining deviations from objectives (if any), revealapaydıning the causes of these deviations, and presenting and directing solutions to identified problems (Başaran, 2000; Yıldırım \& Koçak, 2008).

In the supervision, the most important problem is that the teachers to be supervised will be in passive state during this process, that is, they are excluded from the supervision period and subjected to a mechanical supervision (Aslanargun \& Göksoy, 2013). In a system in which there are about 60 thousand schools, 18 million students and 1 million teachers, it can be observed that there are quantitative deficiencies in the process of supervision and counseling and these deficiencies affect the quality of supervision and counseling actions. It is thought that these problems can be solved by developing a model or an approach that can provide appropriate support and guidance firstly for teachers and readjusting the practices (TEDMEM, 2017). In this respect, an alternative prominent supervision approach is peer supervision. Peer supervision is a process in which teachers in the same branch observe each other's teaching processes, share these observations with the colleagues, reflect upon the effectiveness of these practices and a collaborative environment is created during the process (Bell, 2005). The number of studies on peer supervision in the literature in Turkey is limited. Considering the applicability of the peer supervision in Turkey, it is expected to contribute to the literature.

The ability of math teachers to provide learning to learn skills and to educate creative, intellectual, innovative and collaborative students helps to reach the objectives determined for math teaching in Turkey (Y1ldizl1, 2011). Another reason of selecting math teachers for the study is the critical importance of math teaching since math and mathematical thinking skills are a determinant in the international exams such as PISA, TIMSS. Accordingly, the aim of the study is to determine the opinions of math teachers on peer supervision. The subproblems of the study are presented below:

1) What kind of supervision do math teachers desire?

2) What are the opinions of math teachers on peer supervision?

Method: This study aiming to find out the opinions of math teachers on peer supervision is a case study, a type of qualitative research methods. Yin (2003) divides case study into four categories. In this study, since more than one unit or subunits are embedded in one single case, it is embedded single case study. The sample of the study consisted of nine math teachers. These teachers were chosen with maximum variation sampling method, a type of purposeful sampling. By selecting at least one math teacher from seven geographical regions of Turkey, a diversity in terms of the region where the teachers work was created. In the study, in order to reveal the opinions of the teachers on peer supervision, the related literature was reviewed and then a semi-structured 
interview form prepared suitably with open ended question technique was formed. In order to ensure their validity and reliability, except for the researchers, expert opinions were gathered from two faculty members, one from educational sciences and the other from math teaching department. A pilot study was conducted with two math teachers and the semi-structured interview form was finalized. In the analysis of data, content analysis method was used. As a result of the data analysis performed by the third researcher, inter-rater reliability formula (Miles \& Huberman, 1994) was used and interrater reliability average was found to be $84 \%$.

Results, Discussion, and Conclusion: In the study conducted to determine math teachers' opinions on peer supervision, as a result of the data analysis, 2 main categories namely pre-conditional features and process-oriented features that have 9 subcategories emerged. Under the category of pre-conditional features, there exist the subcategories supervisor's being teacher, physical equipment and bureaucratic conditions. On the other hand, process-oriented features are categorized with the subcategories of objective supervision, supporting development, analyzing the problems, effective communication, collaborative supervision and environment of trust.

When the opinions of the math teachers on peer supervision are investigated, the teachers mentioned that supervision is required to have some preconditional features. These features, according to the math teachers, are as follows: supervisor should be teacher, the physical equipment of the classroom should be adequate and bureaucratic conditions should not obstruct education and supervision. The math teachers stated that there must be certain features that should be considered in the peer supervision process. According to these teachers, there should be an objective supervision throughout the process, teacher development should be supported, supervisors should analyze the problems, effective communication should be established, cooperative supervision should be maintained and this supervision should be done in an environment of trust.

It is believed that peer supervision can be applied as an alternative method in supervising. As Koehler and Mishra (2005) stated it is aimed to educate teachers who have a high level of technological pedagogical content knowledge. Three main dimensions, in this sense, are pedagogy knowledge, field knowledge and technology knowledge. While determining two teachers, if they are chosen based on different skills, that is, one is at a good level of technology knowledge while the other is good at pedagogy knowledge, a collaborative environment can be created where they can develop each other by providing support at the points where they are good and also feel valuable. As the next step, with the meetings held by the specific teacher groups, good practices can be presented to teachers and some discussion sessions can be carried out on these practices. In the current practices as well supervisors/principals may make teachers feel that they believe in the teachers and encourage them for professional development. 


\section{Kaynakça}

Acheson, K. A., \& Gall, M. D. (2010). Clinical supervision and teacher development: Preservice and increase applications (6th Edition). New York: Longman.

Apaydın, Ç. (2014). Bilgi. Norm: Geleneksel okullar neden böyle? [Knowledge. The Norm: Why traditional schools are as they are]. M. B. Aksu \& E. Ağaoğlu (Ed.), Denetim: Yapılandırılmış Liderlik. Gelişimsel Yaklaşım içinde (ss. 19-31). Ankara: Nobel Yayıncilik.

Aslanargun, E., \& Göksoy, S. (2013). Öğretmen denetimini kim yapmalıdır? Uşak Üniversitesi Sosyal Bilimler Dergisi, 14, 98-121.

Aydın, İ. (2016). Öğretimde denetim [Instructional Supervision] (6th Edition). Ankara: Pegem A.

Balc1, B. (2007). Illköğretim müfettişleri ve ilköğretim okulu müdürlerinin: ilköğretim müfettişlerinin rehberlik rollerini gerçekleştirme düzeylerine ilişkin algılar (Yayımlanmamış yüksek lisans tezi). Gazi Üniversitesi Sosyal Bilimler Enstitüsü, Ankara

Başar, H. (1988). Öğretmenlerin değerlendirilmesi. Ankara: Pegem Yayıncıllk.

Başaran, İ. E. (2000). Ĕgitim yönetimi nitelikli okul. Ankara: Feryal Matbaası.

Bauer, K. L. (1987). A comparison of the changes in teachers' stages of concern regarding per observation (Yayımlanmamış Doktora Tezi). Indiana Üniversitesi, Pennsylvania, ABD.

Bell, M. (2005). Peer observation partnerships in higher education. Milperra, NSW: HERDSA Inc.

Bowers, D. L. (1999). Teachers' use of peer observation aand feedback as a means of professional development (Yayımlanmamış Doktora Tezi). Güney California Üniversitesi, UMI: 9933793.

Bozak A., Yıldırım M. C., \& Demirtaş H. (2011). Öğretmenlerin mesleki gelişimi için alternatif bir yöntem: Meslektaş gözlemi. İnönü Üniversitesi Eğitim Fakültesi Dergisi, 12(2), 65-84.

Bozak, A. (2014). Meslektaş rehberliği yönetimi'nin uygulanabilirliğine ve etkililiğine ilişkin ögrretmen görüşlerinin belirlenmesi (Yayımlanmamış Doktora Tezi). İnönü Üniversitesi, Eğitim Bilimleri Enstitüsü, Malatya.

Erdoğan, İ. (1991). İşletmelerde personel seçimi ve başarl değerleme teknikleri. İ.Ü. İşletme Fakültesi Yayınları No: 248, İstanbul.

Ergen, H., \& Eşiyok, İ. (2017). Okul müdürlerinin ders denetimi yapmasına ilişkin öğretmen görüşleri. Çağdaş Yönetim Bilimleri Dergisi, 3(1), 1-19.

Fullan, M. (2000). The return of large-scale reform. Journal of Educational Change, 1, 5-28.

Fullerton, H. (1999). Observation of teaching: A handbook for teaching and learning in higher education. London: Kogan Page.

Gall, J. P., Gall, M. D., \& Borg, W. R. (1999). Applying educational research: A practical guide. New York: Addison Wesley Longman, Inc.

Gordon, T. (2004). Etkili ögretmenlik ĕgitimi (17. Bask1). Çeviri Aksay Emel, İstanbul: Sistem Yayıncıl1k. 
Göksoy, S., \& Aslanargun, E. (2014). Denetim sürecinde eğitim denetmenlerinin davranışları. Bartın Üniversitesi Ĕgitim Fakültesi Dergisi, 3(1), 55-77.

Gümüş E., \& Gümüş S. (2016). Gözlem öncesi görüşme. A. Balcı \& Ç. Apaydın (Ed.), Öğretim denetimi: Uygulama araçları ve kavramlar içinde (ss. 84-100). Ankara: Pegem Akademi.

Gündüz, Y., \& Balyer, A. (2011). Eğitim denetiminde alternatif yaklaşımlar. M. $\ddot{U}$. Atatürk Eğitim Fakültesi Ĕ̆itim Bilimleri Dergisi, 3, 61-78.

Hirsch, L. J. (2011). Utilizing peer observation as a professional development tool to learn in context (Unpublished doctoral thesis). Northeastern University, Boston, Massachusetts, USA, UMI: 3494486.

Karagözoğlu, G. (1977). İlköğretimde teftiş uygulamaları (Yayımlanmamış doçentlik tezi). Hacettepe Üniversitesi, Ankara.

Kazak, E. (2013). Ders denetimindeki uygulama farkl1lıklarına ilişkin öğretmen görüşleri. Anatolian Journal of Educational Leadership and Instruction, 1(1), 1526.

Keskinkılıç, K. (1997). İlköğretim müfettişlerinin denetimdeki kişilik özelliklerine uygun davranışları ve ögretmenlerin onlardan bekledikleri davranışlar (Yayımlanmamış Yüksek Lisans Tezi). Selçuk Üniversitesi, Sosyal Bilimler Enstitüsü, Konya.

Knoll, M. K. (1987). Supervision for better instruction. Englewood: Cliffs, N.J.Prentice Hall.

Koehler, M. J., \& Mishra, P. (2005). What happens when teachers design educational technology? The development of technological pedagogical content knowledge. Journal of Educational Computing Research, 32(2), 131-152

Kohm, B., \& Nance, B. (2009). Creating collaborative cultures. Educational Leadership, 67(2), 67-72.

Kurban, C., \& Tok, T. N. (2018). Okul müdürlerinin performans denetim sistemindeki rolünün, öğretmen görüşlerine göre değerlendirilmesi. Uşak Üniversitesi Sosyal Bilimler Dergisi, 11(1), 1-17.

Marks, J. R., Stoops. E., \& King, J. (1971). Handbook of educational supervision. Boston: Allyn and Bacon Inc.

Miles, H. B., \& Huberman, A. M. (1994). Qualitative data analysis (2nd Edition). Thousand Oaks, CA: Sage.

Milli Eğitim Bakanlığı [MEB], (2000). Milli Eğitim Bakanlı̆̆l ilköğretim okulları müdürlüğü görev tanımı. Tebliğler Dergisi. Sayı: 2508, Tarih: Ocak 2000.

Memduhoğlu, H. B. (2012). Öğretmen, yönetici, denetmen ve öğretim üyelerinin görüşlerine göre Türkiye'de eğitim denetimi sorunsalı. Kuram ve Uygulamada Ĕgitim Bilimleri, 12(1), 135-156.

Nelson, T. R. (2000). Analysis of a peer observation program for graduate teaching assistants to enhance instructional development (Yayımlanmamış doktora tezi). Illinois Üniversitesi, Urbana, Illinois, ABD. UMI: 9971147

Patton, M. Q. (1987). How to use qualitative methods in evaluation. Newbury Park, CA: Sage. 
Potter D. H. (1991). Peer observation and reflection: A strategy for collegial interaction among teachers (Yayımlanmamış doktora tezi). Ohio Devlet Üniversitesi, Ohio, ABD.

Richards, J. C., \& Lockhart, C. (2007). Reflective teaching in second language classrooms (15th Edition). Cambridge, England: Cambridge University Press.

Senge, P, M. (2006). Fifth discipline: The art practice of the learning organization. [Online]: Retrieved on 1.6.2018 at http://www.amazon.com/The-Fifth-DisciplinePractice-Organization/dp/0385517254.

Straughter, B. (2001). The effects of peer observation on self-governance among elementary school teachers (Unpublished Doctoral thesis). Johnson \& Wales University, USA. (UMI: 3042729).

Taymaz, H. (2005). Eğitim sisteminde teftiş: Kavramlar, ilkeler, yöntemler. Ankara: Pegem A Yayıncılık.

TEDMEM (2017). 2017 Ĕ̆itim değerlendirme raporu. 23.01.2018 tarihinde https://tedmem.org/download/2014-egitim-degerlendirme-raporu?wpdmdl=997 adresinden alınmıştır.

Tok, T. N. (2015). Farklı gözlerden maarif müfettişleri. İ. Aydın, \& Ş. Çınkır (Ed.), Prof. Dr. Ibrahim Ethem Başaran'a armă̆an: Eğitimde 52 yll içinde (ss. 291-317). Ankara: Anı Yayınc1lık.

Tonbul, Y., \& Baysülen, E. (2017). Ders denetimi ile ilgili yönetmelik değişikliğinin maarif müfettişlerinin, okul yöneticilerinin ve öğretmenlerin görüşleri açısından değerlendirilmesi. İlköğretim Online, 16(1), 299-311.

Topçuoğlu, N. (2015). Öğretme görüşlerine göre mesleki gelişim: Nitel bir çalışma (Yayımlanmamış Yüksek Lisans Tezi). Mevlana Üniversitesi, Sosyal Bilimler Enstitüsü, Konya.

UNESCO (2007). Roles and functions of supervisors. 28 Temmuz 2011 tarihinde www.unesco.org./iiep adresinden alınmıştır.

Uyanık, M. (2007). Ders teftişinde müfettiş uzmanlaşmasının önemi (Yayımlanmamış Yüksek Lisans Tezi). Muğla Üniversitesi, Sosyal Bilimler Enstitüsü, Muğla.

Ünal, A., (2010). Analysis of perception on supervisors in primary education. Procedia Social And Behavioral Sciences, 2, 5028-5033.

Wahlstrom, K., \& Louis, K.S. (2008). How teachers perceive principal leadership. Educational Administration Quarterly, 44(4), 498-445.

Yağmur, N. (2018). Maarif müfettişleri tarafindan gerçekleştirilen ders denetimlerinin ögretmen performansındaki rolü (Yayınlanmamış Yüksek Lisans Tezi). Düzce Üniversitesi Sosyal Bilimler Enstitüsü, Düzce.

Yıldırım, A., \& Şimşek, H. (2008). Nitel araştırma yöntemleri (7. Baskı). Ankara: Seçkin Yayıncılık

Yıldırım, M. C. (2009). Yapılandırmacı öğrenme paradigması ilkeleri açısından ilköğretim okullarında öğretimsel denetim uygulamalarının değerlendirilmesi (Yayınlanmamış doktora tezi). İnönü Üniversitesi Sosyal Bilimler Enstitüsü, Malatya. 
Yıldırım, İ., \& Koçak, Ş. (2008). Eğitim denetiminde ilköğretim müfettişleri yetiştirilmesi ve sorunlart. 12.02 .2018 tarihinde http://www.cu.edu.tr/insanlar/kocaks/ adresinden alınmıştır.

Yıldırım, N. (2012). Eğitim denetmeni ve Bakanlık denetmeni imajları üzerine karş1laştırmalı bir çalışma. Kuram ve Uygulamada Ĕ̌itim Yönetimi, 18(1), 143166.

Y1ldızlı, H. (2011). Illköğretim matematik öğretmenlerinin genel ögretmenlik davranışları açısından kendilerine yönelik yeterlik algıları (Ankara ili örneği) (Yayımlanmamış Yüksek Lisans Tezi). Selçuk Üniversitesi, Eğitim Bilimleri Enstitüsü, Konya.

Y1lmaz, K. (2009). Okul müdürlerinin denetim görevi, İnönü Üniversitesi Ĕ̆itim Fakültesi Dergisi, 10(1), 19-35.

Yin, R. K. (2003). Case study research: Design and methods (Third Edition). New Delhi: London.

Yin, R. K. (2009). Case study research: Design and methods (Forth Edition). Thousand Oaks, CA: Sage

Yurdakul, A., \& Tok, T. N. (2017). Maarif müfettişlerinin görev alanlarına ilişkin görüşleri. Journal of Human Sciences, 14(4), 5008-5019.

This is an Open Access article distributed under the terms of the Creative CommonsAttributionNonCommercial-ShareAlike 4.0 International (CC BY-NC-SA 4.0). For further information, you can refer to https://creativecommons.org/licenses/by-nc-sa/4.0/ 